\title{
Distance Learning
}

National Cancer Institute

\section{Source}

National Cancer Institute. Distance Learning. NCI Thesaurus. Code C18157.

Refers to the process by which students and teachers at different sites carry out learning and instruction via cable connection, conventional phone lines, or computer networks. 